\title{
A Normal Country: Russia After Communism
}

\section{Citation}

Shleifer, Andrei, and Daniel Treisman. 2005. A Normal Country: Russia After Communism. Journal of Economic Perspectives 19, no. 1: 151-174. doi:10.1257/0895330053147949.

\section{Published Version}

doi:10.1257/0895330053147949

\section{Permanent link}

http://nrs.harvard.edu/urn-3:HUL.InstRepos:33078568

\section{Terms of Use}

This article was downloaded from Harvard University's DASH repository, and is made available under the terms and conditions applicable to Other Posted Material, as set forth at http:// nrs.harvard.edu/urn-3:HUL.InstRepos:dash.current.terms-of-use\#LAA

\section{Share Your Story}

The Harvard community has made this article openly available.

Please share how this access benefits you. Submit a story.

Accessibility 


\section{A Normal Country: Russia After Communism}

\section{Andrei Shleifer and Daniel Treisman}

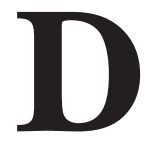

uring the 1990s, Russia underwent extraordinary transformations. It changed from a communist dictatorship into a multiparty democracy in which officials are chosen in regular elections. Its centrally planned economy was reshaped into a capitalist order based on markets and private property. Its army withdrew peacefully from eastern Europe and the former Soviet republics, allowing the latter to become independent countries. Twenty years ago, only the most naïve idealist could have imagined such a metamorphosis.

Yet the mood among Western observers has been anything but celebratory. By the turn of the century, Russia had come to be viewed as a disastrous failure and the $1990 \mathrm{~s}$ as a decade of catastrophe for its people. Journalists, politicians and academic experts typically describe Russia not as a middle-income country struggling to overcome its communist past and find its place in the world, but as a collapsed and criminal state.

In Washington, both left and right have converged on this view. To Dick Armey, then Republican House majority leader, Russia had by 1999 become "a looted and bankrupt zone of nuclearized anarchy" (Schmitt, 1999). To his colleague, Banking Committee Chairman James Leach (1999a, b), Russia was "the world's most virulent kleptocracy," more corrupt than even Mobutu's Zaire. Bernard Sanders (1998), the socialist congressman from Vermont, described Russia's economic performance in the 1990 s as a "tragedy of historic proportions"; liberal reforms had produced only "economic collapse," "mass unemployment" and "grinding poverty."

More recently, a glimmer of optimism returned. President Bush, in late 2003, praised President Putin's efforts to make Russia into a "country in which democracy

Andrei Shleifer is Whipple V. N. Jones Professor of Economics, Harvard University, Cambridge, Massachusetts. Daniel Treisman is Associate Professor of Political Science, University of California at Los Angeles, Los Angeles, California. 
and freedom and the rule of law thrive" (U.S. Department of State, 2003). But the happy talk did not last long. When Russian prosecutors arrested the oil tycoon Mikhail Khodorkovsky in October 2003, New York Times columnist William Safire (2003b) reported that Russia was now ruled by a "power-hungry mafia" of former KGB and military officers, who had grabbed "the nation by the throat." When the pro-Putin United Russia Party was announced to have won more than 37 percent of the vote in the December 2003 parliamentary election, Safire (2003a) lamented the return of "one-party rule to Russia," and declared the country's experiment with democracy "all but dead."

Are conditions in contemporary Russia as bad as the critics contend? In this article, we examine the country's recent economic and political performance, using a variety of data on growth, macroeconomic stability, income inequality and company finances, as well as reports of election monitors and surveys of business people and crime victims. We find a large gap between the common perception and the facts. After reviewing the evidence, the widespread image of Russia as a uniquely menacing disaster zone comes to seem like the reflection in a distorting mirrorthe features are recognizable, but stretched and twisted out of all proportion.

In fact, although Russia's transition has been painful in many ways, and its economic and political systems remain far from perfect, the country has made remarkable economic and social progress. Russia's remaining defects are typical of countries at its level of economic development. Both in 1990 and 2003, Russia was a middle-income country, with GDP per capita around $\$ 8,000$ at purchasing power parity according to the UN International Comparison Project, a level comparable to that of Argentina in 1991 and Mexico in 1999. Countries in this income range have democracies that are rough around the edges, if they are democratic at all. Their governments suffer from corruption, and their press is almost never entirely free. Most also have high income inequality, concentrated corporate ownership and turbulent macroeconomic performance. In all these regards, Russia is quite normal. ${ }^{1}$ Nor are the common flaws of middle-income, capitalist democracies incompatible with further economic and political progress.

To say that Russia has become a "normal" middle-income country is not to overlook the messiness of its politics and economics or to excuse the failures of its leaders. Most middle-income countries are not secure or socially just places to live. Nor are all middle-income countries alike. None of the others has Russia's nuclear arms or its pivotal role in international affairs. Yet other countries around Russia's level of income-from Mexico and Brazil to Malaysia and Croatia-face a common set of economic problems and political challenges, from similarly precarious vantage points. Russia's struggles to meet such challenges closely resemble those of its peers. In the next section, we provide a brief review of key events in Russia's transition, before plunging into a more detailed examination of the facts.

\footnotetext{
${ }^{1}$ We are not the first to call Russia "normal." Boris Yeltsin used this term in 1994 in his memoir The Struggle for Russia - a little earlier than we would have. Mary Dejevsky, "The Prophets of Doom Were Wrong About Russia," The Independent, December 26, 2001, also used this language.
} 


\section{Russia After Communism}

In June 1991, Boris Yeltsin became Russia’s first elected president. In December, following a failed putsch by communist hardliners that August, Yeltsin agreed with the leaders of Ukraine and Belarus to dissolve the Soviet Union, leaving Russia independent. Yeltsin's elevation followed several years of partial reform under the last Soviet leader, Mikhail Gorbachev. The previous two years had seen declines in output, worsening shortages and fears of a complete economic and political collapse. In 1989, the average citizen spent 40-68 hours a month standing in line. By April 1991, fewer than one in eight respondents to an opinion poll said they had recently seen meat in state stores, and fewer than one in 12 had seen butter (Aron, 2002). In fall 1991, CNN predicted starvation that winter.

Once in power, Yeltsin introduced radical economic reforms. In January 1992, most prices were liberalized. Queues disappeared and goods reappeared in stores. A mass privatization program, implemented during 1993-1994, transferred shares in most firms from the government to their managers, workers and the public. By mid-1994, almost 70 percent of the Russian economy was in private hands. In 1995, with the help of the International Monetary Fund, Russia stabilized the ruble. Enacting these reforms proved extremely difficult. The parliament, the unreformed and well-organized Communist Party, and entrenched industrial interests resisted almost every measure.

In 1995, Yeltsin tried to broaden his support ahead of the 1996 presidential election, which the Communist Party leader, Gennady Zyuganov, was expected to win. As part of this political campaign, and in an attempt to balance the budget, Yeltsin agreed to a "loans-for-shares" program, whereby some valuable natural resource enterprises were turned over to major businessmen in exchange for loans to the government. This highly controversial program accelerated the consolidation of a few large financial groups, led by so-called "oligarchs," who enjoyed great political and economic influence. The oligarchs helped Yeltsin with sympathetic coverage on the television networks and in the newspapers they owned.

Despite suffering a heart attack, which was concealed from the voters, Yeltsin won a second presidential term. He accomplished the goal of his life: to prevent communists from regaining power in Russia. But he was a sick man, lacking political and popular support, and much of his focus was on finding a successor. Political gridlock made it hard for the government to collect taxes. As oil prices collapsed in 1997-1998, so did the federal budget, and the financial turmoil that had started in east Asia spread to Russia. The crisis led to a Russian debt default and a sharp depreciation of the ruble; yet, contrary to the expectations of most pundits, it was followed by a rapid economic recovery.

Yeltsin's foreign and military policies during this period were equally radical. He reduced defense procurement by an estimated 90 percent, pursued drastic nuclear arms reduction in co-operation with the United States, accepted the expansion of NATO, and participated in U.N.-led efforts to stop civil war in the former Yugoslavia. But Russia also started a war in Chechnya that led to tens of thousands of casualties. 
Yeltsin ultimately found a successor, Vladimir Putin, whom he appointed Prime Minister in 1999. On January 1, 2000, Yeltsin resigned and Putin became Acting President, subsequently winning the presidential election in March of that year. Over the following four years, Russia's economy grew rapidly, helped by increases in oil prices and the continuing benefits of exchange rate depreciation. By 2003, the Russian government was borrowing money in world markets long term at an interest rate of around 7 percent, indicating significant investor confidence. Most forecasts for Russia's economic growth had turned highly optimistic.

\section{Economic Cataclysm?}

\section{The Output "Collapse"}

Russia started its transition in the early 1990s as a middle-income country. The United Nations International Comparison Project, which calculates cross-nationally comparable income figures, estimates that Russia's per capita GDP as of 1989 was $\$ 8,210$ - around the level of Ukraine, Argentina, Latvia and South Africa. (By 1991, when Gorbachev left office, it had fallen to $\$ 7,780$.) This level was higher than Mexico and Brazil, but only about 65-75 percent of that in poorer west European countries such as Portugal, Greece and Spain; less than half the level of France or Italy; and just over one-third that of the United States.

That Russia's output contracted catastrophically in the 1990s has become a cliché. According to official Goskomstat statistics, Russian GDP per capita fell about 39 percent in real terms between 1991, when Gorbachev left office, and 1998, when the economic recovery started. ${ }^{2}$

Yet there are three reasons to think that Russia's economic performance in the 1990s was actually far better. First, official statistics greatly exaggerate the true value of Russia's output at the beginning of the decade. Much of recorded GDP under the Soviet Union consisted of military goods, unfinished construction projects, and shoddy consumer products for which there was no demand. In the early 1990s, military procurement dropped sharply. With the introduction of markets, firms also stopped making consumer goods they could not sell. Cutting such production reduces reported economic output, but does not leave consumers any worse off. Moreover, much of reported output under the Soviet system was simply fictitious. To obtain bonuses, managers routinely inflated their production figures. With the end of central planning, managers now wished to underreport output so as to reduce their tax bill. Consequently, Russia's economic decline was probably smaller than officially reported (Aslund, 2002). ${ }^{3}$ 
Second, Russia's unofficial economy grew rapidly in the 1990s. Estimating unofficial activity is difficult. But one common technique for measuring the growth of the whole economy-both official and unofficial-is to use electricity consumption, on the theory that even underground firms must use electricity (Johnson, Kaufmann and Shleifer, 1997). Figure 1 shows the trend in reported GDP, deflated for price rises, between 1990 and 2002, alongside figures for electricity consumption. While official GDP fell 26 percent in this period, electricity consumption fell only 18 percent. This suggests that Russia's output decline in the 1990s was not as sharp as the official statistics indicate. Since under market conditions firms are likely to use electricity more rationally, even the observed decline in electricity consumption may overstate the output drop. ${ }^{4}$

Third, other statistics suggest that average living standards fell little during the decade, and, in some important respects, improved. Retail trade (in constant prices) rose 16 percent between 1990 and 2002, as shown in Figure 1. Goskomstat's figures for final consumption of households (in constant prices) rose by about 3 percent during 1990-2002. Average living space increased from 16 square meters per person in 1990 to 19 in 2000, and the share of this living space owned by citizens doubled during the decade, from 26 to 58 percent (Goskomstat, 2001, p. 200). The number of Russians going abroad as tourists rose from 1.6 million in 1993 to 4.3 million in 2000 . The shares of households with radios, televisions, tape recorders, refrigerators, washing machines and electric vacuum cleaners all increased between 1991 and 2000. Private ownership of cars doubled, rising from 14 cars per 100 households in 1991 to 27 in 2000, with large increases occurring in almost all regions (Goskomstat, 2001, pp. 193-194). At the same time, however, consumption of some previously state-provided or state-subsidized services-trips to the movies, theaters, museums and state-subsidized summer camps for childrenfell.

Russia has, without doubt, experienced an increase in inequality (as we discuss below). But some indicators suggest improvement also toward the bottom of the social pyramid. Since 1993 (when comprehensive figures begin), the proportion of Russia's housing with running water has increased from 66 to 73 percent; the share with hot water grew from 51 to 59 percent; and the percentage with central heating rose from 64 to 73 percent. Since 1990, the proportion of apartments with telephones has increased from 30 to 49 percent (Goskomstat, 2001, pp. 201, 468).

One indicator often taken as evidence of a catastrophic decline in living standards is the sharp drop in Russian life expectancy in the 1990s. Between 1990 and 2000, average life expectancy fell by about four years, from 69.2 to 65.3.

account consumer substitution away from higher-priced goods, and therefore overstates the effect of rising prices on living standards when-as occurred in Russia-the prices of different goods rise at very different rates. See Gibson, Stillman and Le (2004).

${ }^{4}$ If electricity consumption by households and the government itself fell less than that by producers, the total drop in electricity consumption might understate the drop in economic output. However, rough calculations suggest the share of households was very low-maybe on the order of 4-6 percent of the total. Our guess is that use by the government was even lower. 
Figure 1

\section{Measuring Economic Change in Russia, 1990-2002}

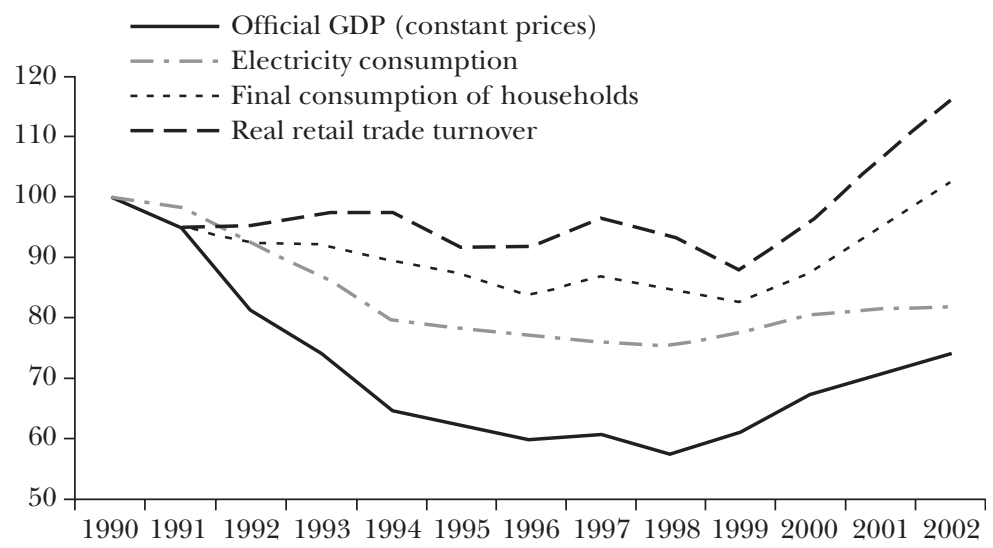

Source: Goskomstat Rossii, Rossiiskiy Statisticheskiy Yezhegodnik 2001, 2003, Rossia v Tsifrakh 2002, Goskomstat updates.

However, as Cutler and Brainerd show in their contribution to this symposium, this does not seem to be related to increased poverty, malnutrition or poorer access to health care. If poverty were to blame, one might expect the death rate to rise most among the most economically vulnerable groups. In the early 1990s, the poverty rate was highest among children aged 7 to 15; among adults, it was higher among women than men. But there was practically no increase in mortality among children of any age, and the death rate jumped much more for men than for women (Goskomstat, 2001, p. 126). Higher mortality is also hard to link to malnutrition. In 1992-1993, as the death rate jumped sharply, the Russian Longitudinal Monitoring Survey found no evidence of serious malnutrition in Russia. In fact, the proportion of people whose body weight increased during these years exceeded the share that lost weight (Shkolnikov, Cornia, Leon and Meslé, 1998). As for access to health care, the percentage of adults getting required checkups fell slightly, from 89 percent in 1990 to 86 percent in 1992, before rising to 91 percent in 2000 (Goskomstat 2001, p. 246). The state's fiscal crisis did reduce resources of the health system in some ways. But in other ways, resources increased. The number of doctors per capita, already one of the highest in the world, rose still higher in the 1990s (Goskomstat, 2001, p. 242). Infant mortality-one indicator of the effectiveness of basic health care-although rising a little initially, fell during the decade, from 17.4 per 1,000 live births in 1990 to 15.3 in 2000 (Goskomstat, 2001, p. 127).

Most specialists agree that the rise in mortality in the early 1990s, concentrated as it was among middle-aged men, had much to do with increasing alcohol abuse (Shkolnikov, Cornia, Leon and Meslé, 1998; DaVanzo and Grammich, 2001). This may have been stimulated by a sharp drop in the relative price of vodka in these years. For the average monthly income, Russians could buy 10 liters of vodka in 
1990, but 47 in $1994 .{ }^{5}$ Several causes of death that increased dramatically have been associated with binge drinking (Shkolnikov, Cornia, Leon and Meslé, 1998). Stress induced by the economic transition may also have contributed, as Brainerd and Cutler argue in this journal. Either way, there is little sign the increased death rate was caused by falling income. As per capita GDP rose by about 30 percent between 1998 and 2002, life expectancy again dropped by 2.2 years.

A close look at Figure 1 also casts doubt on the popular theory that Russia's economic decline was caused by misguided government policies pursued in the 1990s, especially Yeltsin's privatization program and his "loans-for-shares" scheme (Goldman, 2003). As Figure 1 makes clear, most of the fall in both Russia's official GDP and electricity consumption occurred prior to 1994, before the significant part of the mass privatization program was completed and before the "loans-forshares" program was even contemplated.

Comparing Russia's economic performance in the 1990s to that of other postcommunist countries suggests two additional points, illustrated in Figure 2. First, officially measured output fell in all the postcommunist economies of eastern Europe and the former Soviet Union, with no exceptions. It declined in new democracies, such as Russia and Poland, and in continuing dictatorships, such as Belarus and Tajikistan; in rapid reformers, such as the Czech Republic and Hungary, and in very slow reformers, such as Ukraine and Uzbekistan. The universality of the contraction suggests common causes. One possibility is a universal decrease in military and economically useless activities that were previously counted as output. A second is the temporary dislocation that all countries experienced as their planning systems disintegrated (Murphy, Shleifer and Vishny, 1992; Blanchard and Kremer, 1997). Consistent with both these explanations, officially measured output began to recover after a few years almost everywhere. Second, the depth of the measured contraction was greater in some countries than in others. Generally, it was smaller in eastern Europe and the Baltic states than in the rest of the former Soviet Union. Russia's official output fell slightly less than average for the 14 former Soviet republics for which figures are available. ${ }^{6}$

The patterns of decline in the postcommunist countries challenge another common theory about the output contraction. Some argue that excessive speed of reform exacerbated the decline and compare the "gradualism" of China's economic policies favorably to the "shock therapy" of Russia's. In fact, among the east European and former Soviet countries, there is no obvious relationship between speed of reform and change in official output. Comparisons across these countries must be tentative since the quality of statistics varies, and the uneven impact of civil disorder and war complicates drawing connections between economic policy and performance. However, among the countries that contracted least according to the

\footnotetext{
${ }^{5}$ Calculated from Russian Economic Trends database and Goskomstat (1994, p. 288), Goskomstat (2001, p. 588).

${ }^{6}$ One might have expected that the shift to world market prices in trade among the former communist countries would have disproportionately benefited Russia, which had been exporting subsidized energy to other eastern bloc countries.
} 
Figure 2

\section{Official GDP Per Capita in Postcommunist Countries, First 10 Years of Transition} (at constant prices)

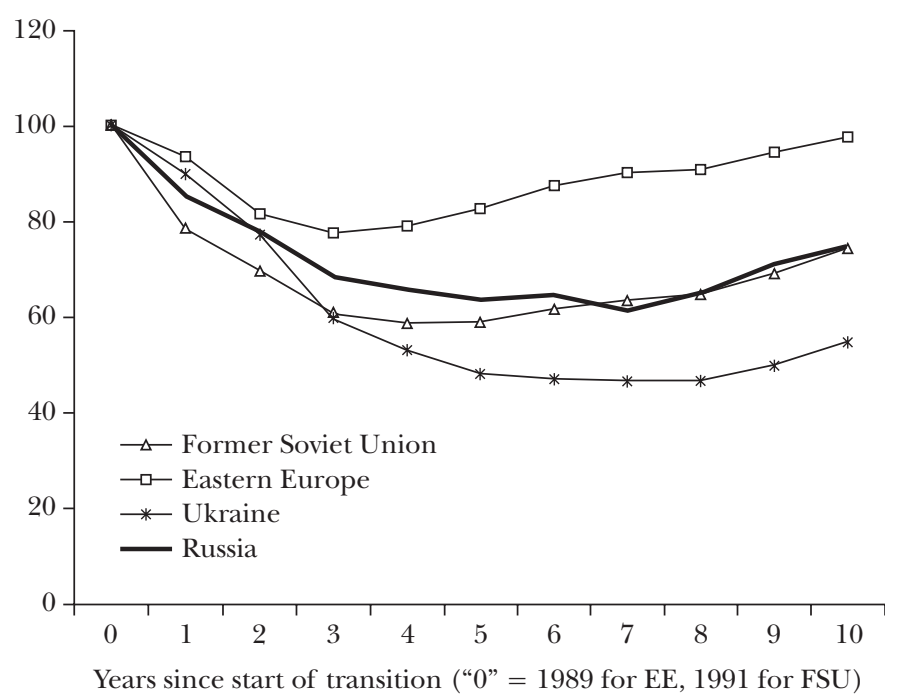

Source: Calculated from World Bank, World Development Indicators 2003 and EBRD Transition Report 1997. Eastern Europe: unweighted average of Albania, Bulgaria, Hungary, Poland, Romania, Slovakia, Slovenia. Former Soviet Union: unweighted average of Armenia, Belarus, Estonia, Georgia, Kazakhstan, Kyrgyzstan, Latvia, Lithuania, Moldova, Russia, Tajikistan, Turkmenistan, Ukraine, Uzbekistan. Data unavailable for Azerbaijan.

official figures are both rapid reformers (Estonia, Poland, Czech Republic) and slow or nonreformers (Belarus, Uzbekistan). Those with the largest declines also include both nonreformers (Tajikistan, Turkmenistan) and some that tried to reform (Moldova). A comparison of Russia with Ukraine is particularly instructive (see Figure 2). Ukraine had a large population (about 52 million), an industrial economy, significant natural resources and a "culture" similar to Russia's prior to transition. Unlike Russia, it retained the old communist leadership, albeit renamed, and pursued more cautious reforms, keeping a much larger share of the economy in state hands. Yet Ukraine's official drop in per capita GDP of 45 percent between 1991 and 2001 was almost twice as large as Russia's.

In comparison with other nations of eastern Europe and the former Soviet Union, Russia's economy performed roughly as one might have expected. Our best estimate is that its genuine output drop between 1990 and 2001 was small and probably completely reversed by 2003 (Aslund, 2003). Considering the distorted demand, inflated accounting and uselessness of much of the prereform output, Russians today are probably on average better off than they were in 1990.

\section{Financial Crises}

The 1990s was a decade of extreme macroeconomic turbulence for Russia. Between December 1991 and December 2001, the ruble's value dropped by more 
than 99 percent against the dollar. Three years after the authorities managed to stabilize inflation in 1995, a financial crisis led to a devaluation of the ruble and a government moratorium on foreign debt payments.

But such financial crises are common among emerging market economies. Bad as the 99 percent drop in the ruble's value sounds, an examination of the IMF's International Financial Statistics (April 2002) shows that eleven other countriesincluding Brazil, Turkey, Ukraine and Belarus-suffered even larger currency declines during the 1990s. In the 1980s, depreciations this large were even more frequent, with larger ones recorded by Peru, Argentina, Bolivia, Brazil, Uruguay, Nicaragua, Vietnam, Lebanon and even Poland, later seen as the greatest success story of transition from socialism.

During Russia's 1998 crisis, the ruble fell 61 percent in the two months of August and September. But during the decade from January 1992 to December 2001, two-month currency collapses at least this large occurred 34 times, in a total of 20 countries. Russia's crash in 1998 was not an isolated phenomenon: it came in the middle of a wave of similar currency crises that stretched from Thailand and Indonesia to Brazil and Turkey. Moreover, the consequences of Russia's 1998 financial crisis were far less dire than claimed at the time. The devaluation was followed by a multiyear spurt of rapid growth and a reinvigorated drive toward liberal economic reform.

\section{Economic Inequality}

Russia's economic reforms are said to have exacerbated economic inequality, with privatization often fingered as the primary culprit. The European Bank for Reconstruction and Development (1999, p. 110) wrote: "[U]nder the 'shares-forloans' scheme implemented in 1995, many of the key resource-based companies fell into the hands of a small group of financiers, the so-called 'oligarchs.' This has led to very sharp increases in wealth and income inequality-by 1997 the Gini coefficient for income in Russia was around 0.5."7

Inequality has increased sharply in Russia since the fall of communism. There is some question about the precise numbers, but no dispute about the trend. Russia's official statistical agency, Goskomstat (2001, p.187), shows the Gini coefficient for money incomes rising from .26 in 1991 to .41 in 1994, after which it stabilized at about .40 through the end of the decade. ${ }^{8}$ The World Bank, in various issues of the annual World Development Reports and World Development Indicators, gives

\footnotetext{
${ }^{7}$ The Gini coefficient ranges from 0 to 1 , where 0 means perfect equality (everyone has the same income) and 1 means perfect inequality (one person has all the income). To calculate the Gini coefficient, plot a "Lorenz curve" where the horizontal axis is the cumulative percentage of households, ranging up to 100 percent, and the vertical axis is the cumulative percentage of income held by those households, also ranging up to 100 percent. A straight line, going up at a 45-degree angle, will show perfect equality of income. If the area between the line of perfect equality and actual Lorenz curve is $A$, and the area underneath the line that shows perfect equality of income is $B$, the Gini coefficient is $A / B$. ${ }^{8}$ On the other hand, relative equality of incomes in the shortage economy of late socialism existed alongside highly unequal access to consumer goods.
} 
figures for Russia’s Gini for expenditure of .496 in 1993, .480 in 1996, .487 in 1998, and .460 in 2000. For comparison, the Goskomstat figure of .41 is almost exactly the same as that for the United States (.408 in 1997). The higher World Bank estimate of .496 is about that of Malaysia (.492) or the Philippines (.462), but below that of Hong Kong (.522), Mexico (.531), South Africa (.593) or Brazil (.607).

The trouble with the claim that privatization caused inequality is that inequality came first. Russia's Gini coefficient rose sharply between 1991 and 1993, and peaked in 1994, before any effects of privatization could possibly materialize. Nor is unemployment responsible. In 1992-1993, unemployment remained below 6 percent. It was in 1994-1998 that it grew to 13.2 percent, while inequality declined slightly (Goskomstat, 2001, p. 133). The growth of entrepreneurial income also played at most a limited role. Branko Milanovic (1998, p. 22) of the World Bank finds that 77 percent of the inequality increase can be attributed to growing dispersion of wage incomes. While some Russians worked in successful firms that rapidly benefited from free prices and open trade, others remained in declining firms and in the state sector. Unfortunate as the growth of inequality has been, it is largely the result of the upheavals associated with rationalizing economic activity.

\section{Oligarchical Capitalism}

Russia's economic reforms are often said to have fueled the rise of a small class of "oligarchs," who stand accused of stripping assets from the companies they acquired. This, in turn, is said to have depressed investment and economic growth (Stiglitz, 2002; Hoff and Stiglitz, 2002).

Russia's big business is certainly dominated by a few tycoons, as Guriev and Rachinsky argue in their contribution to this symposium. However, in this Russia is quite typical. In almost all developing capitalist economies and even in most developed countries, the largest firms are either state or family controlled, with a few dominant families often controlling a large share of national production through financial and industrial groups (La Porta, Lopez-de-Silanes and Shleifer, 1999; Claessens, Djankov and Lang, 1999). This is overwhelmingly true of middleincome countries, such as Mexico, Brazil, South Korea, Malaysia or South Africa, but it also applies to developed countries such as Italy, Singapore and Sweden. The big business families are inevitably politically connected, sometimes receiving loans and subsidies from the government (as in South Korea and Italy), often actively participating in privatization (as in Mexico and Brazil) and quite regularly holding high government offices while retaining a connection to their firms (as in Italy and Malaysia) (Faccio, 2003). Following the Asian financial crisis of 1998, this system of political ownership and control has been pejoratively rechristened "crony capitalism," even though it has been associated with some of the most rapid growth ever seen, as well as a remarkable recovery from crisis in Malaysia and South Korea. Such patterns of ownership have also emerged in transition economies from Latvia to the central Asian states.

Have Russia's oligarchs depressed economic performance? Russia's tycoons, like those elsewhere in the developing world (not to mention America's robber 
barons of the nineteenth century), grew rich in part through deals with the government. But the claim that this accounts for poor growth in Russia makes little sense. Russia's sharp decline in official output came before-not after-the oligarchs emerged on the scene in 1995-1996. A few years of stagnation followed and then rapid growth. Oligarch-controlled companies have performed extremely well, and far better than many comparable companies that remained controlled by the state or by their Soviet-era managers. They are responsible for much of the dramatic increase in output in recent years, as well as the amazing stock market boom.

Consider three of the most notorious cases. In "loans-for-shares," Mikhail Khodorkovsky (now in jail) obtained a major stake in the oil company Yukos. Boris Berezovsky (now in exile), won control of the oil company Sibneft along with his then-partner Roman Abramovich. Vladimir Potanin acquired the nickel producer Norilsk Nickel. Between 1996 and 2001, the reported pretax profits of Yukos, Sibneft and Norilsk Nickel rose in real terms by 36, 10 and 5 times, respectively. ${ }^{9}$ Their stock market valuations also soared (those of Yukos and Sibneft rising by more than 30 times in real terms). This performance is markedly better than that of the gas monopoly Gazprom or the electricity utility UES, which stayed under state control, or of major private companies, such as Lukoil, that remained controlled by preprivatization management (Boone and Rodionov, 2001).

Have the oligarchs stripped assets from the companies they acquired in privatization? The audited financial statements of these companies suggest they actually invested, especially since 1998. Yukos' assets rose from $\$ 5.3$ billion in 1998 to $\$ 14.4$ billion in 2002 , although this might reflect in part higher world oil prices (see Table 1). Norilsk Nickel's assets rose from $\$ 6.6$ billion in 1999 to $\$ 9.7$ billion in 2002. Sibneft's assets did fall from 1996 to 1999, in part due to an accounting change (which might reflect asset stripping). But since 1999, they have increased from $\$ 4.3$ billion to $\$ 7.5$ billion in 2002 . Recently, the major oligarchs have been investing hundreds of millions of dollars annually in their companies. In 2002, Yukos invested $\$ 1.26$ billion in property, plant, and equipment, and Sibneft made capital expenditures of $\$ 959$ million. Guriev and Rachinsky (2004), in a systematic study of the performance of oligarch-controlled companies in 2001, found that such companies invested significantly more that year than firms controlled by other Russian owners.

In contrast, the greatest asset stripping scandals have concerned companies that remained under state control. Gazprom's former management has been accused of stealing assets via complicated networks of trading companies. The state-owned airline Aeroflot's reported assets dropped between 1998 and 2001. By and large, the companies privatized to the oligarchs performed far better than those left under state control. That the leading oligarch-controlled oil companies generally outperformed other oil firms such as Lukoil, which remained under 
Table 1

Total Assets and Investment of Three Leading Russian Companies

\begin{tabular}{lccccccr}
\hline \hline & 1996 & 1997 & 1998 & 1999 & 2000 & 2001 & 2002 \\
\hline $\begin{array}{l}\text { Yukos } \\
\quad \text { Total assets, bn US \$ }\end{array}$ & 4.7 & 5.2 & 5.3 & 6.0 & 10.3 & $10.5^{\mathrm{e}}$ & $14.4^{\mathrm{e}}$ \\
$\quad$ Investment, ${ }^{\mathrm{e}}$ mn US \$ & & & & 226 & $589^{\mathrm{e}}$ & $954^{\mathrm{e}}$ & $1263^{\mathrm{e}}$ \\
$\begin{array}{l}\text { Sibneft } \\
\quad \text { Total assets, bn US \$ }\end{array}$ & 7.6 & $5.6^{\mathrm{d}}$ & 5.0 & 4.3 & 4.6 & 5.7 & 7.5 \\
$\quad$ Investment, ${ }^{\mathrm{b}}$ mn US $\$$ & & & 154 & 129 & 231 & 619 & 959 \\
$\quad \begin{array}{l}\text { Norilsk Nickel } \\
\text { Total assets, bn US \$ }\end{array}$ & & & & 6.6 & 7.2 & $10.9^{\mathrm{c}}$ & 9.7 \\
$\quad$ Investment, ${ }^{\mathrm{b}}$ mn US $\$$ & & & & 168 & 638 & $510^{\mathrm{c}}$ & 351 \\
\hline
\end{tabular}

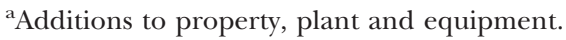

${ }^{\mathrm{b}}$ Capital expenditures.

${ }^{c}$ Restated in 2002 Annual Report.

${ }^{\mathrm{d}}$ Assets reduced by $\$ 1.3$ bn because of accounting change.

eAs in 2002 Annual Report.

Sources: Audited financial statements and annual reports.

Soviet-era management, suggests that their success was due to better management and not only to rising oil prices.

None of this is to say the oligarchs are public spirited, politically naïve or protective of their minority shareholders. They benefited from sweetheart deals with the government and massively diluted the value of minority shares in order to consolidate their control. Investor protection and corporate governance in Russia remain weak. But here again, Russia is typical of middle-income developing countries, where expropriation of minority shareholders is nearly universal (Johnson, La Porta, Lopez-de-Silanes and Shleifer, 2000).

In fact, the claim that the oligarchs privatized companies in order to strip their assets and are impeding economic growth has it precisely backward. The oligarchs stripped assets from state-controlled companies in order to buy others in privatization. Indeed, the concern with such theft from state firms was one of the reasons to accelerate privatization in 1992. The oligarchs also tried to buy assets in privatization at the lowest possible prices, often offering politicians various deals. Once in control, they attempted to increase their ownership stakes, both legally and illegally. But once oligarchs became full owners, they acted as economic theory predicts: they invested to improve their companies' performance. This is what oligarchs have done in every other country-from J.P. Morgan and John D. Rockefeller to Silvio Berlusconi and the owners of Korean chaebol.

In sum, Russia's economy is not a model of capitalism that one finds in introductory textbooks. Like other middle-income countries, Russia suffers from inequality, financial crises and a large unofficial sector. Economic and political power are intimately intertwined. Nonetheless, Russia started the 1990s a disintegrating, centrally planned economy and ended it a market system in a burst of rapid growth. 


\section{Autocratic Kleptocracy?}

\section{Democracy}

Western evaluations of Russia's political institutions in the last ten years have often been scathing. Even before Putin's recent consolidation of power, The Economist magazine declared the country's democracy to be "phony" (June 24, 2000, p. 20). The advocacy group Freedom House, which rates countries' institutions, has since 2000 given Russia a " 5 " for political freedom and a " 5 " for civil liberties on a seven-point scale that ranges from "1" (highest) to "7" (lowest). This puts Russia's political regime below Brazil's military junta of the late 1970s and its civil liberties below those of Nigeria in 1991 under the dictatorship of Major General Ibrahim Babangida. According to Freedom House's own report, in Nigeria at this time military tribunals were charged with trying cases of sedition and the regime had made a practice of incarcerating "innocent relatives of suspected political offenders to draw the suspects out of hiding” (Gastil, 1992, p. 353). Even Kuwait, a hereditary emirate where political parties are illegal, women cannot vote in legislative elections and criticism of the emir is punishable by imprisonment, gets a better rating for political freedom than Russia.

Critics of Russia's democracy focus on several points. Those in power are accused of manipulating elections through control of the state media, harassment or censorship of the independent press and use of judicial and administrative levers to intimidate or incapacitate rivals. Voters are portrayed as apathetic and gullible. At the same time, big business is seen as subverting the democratic process through financial support of favored candidates. The combination of voter apathy and official manipulation means, in the grim but quite representative view of one New York Times reporter, that in Russia during the last decade "there has been no truly democratic choice of new leaders" (Myers, 2003).

Just how bad is Russia's democracy? Russia's political institutions and civic freedoms are certainly imperfect in many ways. Relative to that under Yeltsin, the situation under President Putin has deteriorated considerably and could deteriorate further. However, Western condemnations of Russia's institutions in the last 10 years have been grossly overblown. Russia's politics have been among the most democratic in the region. The defects of the country's democracy resemble those found in many other middle-income countries.

Eight national ballots-four parliamentary and four presidential-took place in Russia between 1991 and 2004. A variety of candidates ran in each, representing all parts of the political spectrum. With few exceptions, parties and electoral blocs were free to organize, and a large number managed to register. International observers, although critical of imbalance in media coverage and episodic improprieties, have generally given these elections high marks. The Organization for Security and Cooperation in Europe (OSCE), a regional security organization headquartered in Austria with 55 member nations, regularly monitors elections in Russia and other countries. Its report on the 1999 Russian Duma election, for instance, praised the country's electoral laws for providing "a sound basis for the conduct of orderly, pluralistic and accountable elections" and the vote-counting 
procedures for "transparency, accountability and accuracy that fully met accepted international standards." The OSCE's predecessor organization, the Conference for Security and Cooperation in Europe, reported after the 1993 election that voters had been able to "express their political will freely and fairly" and called the 1995 election "free and fair." 10

Does such language merely reflect a reluctance to criticize? Such fears are belied by the OSCE's blunt condemnations of elections in other nearby countries, such as Azerbaijan in 2000 ("primitive falsification"), Georgia in 2000 ("ballot stuffing and protocol tampering" that "has discredited Georgia's democratization") and Ukraine in 1999 ("flagrant violations of voting procedures" and a "widespread, systematic, and co-ordinated campaign by state institutions at all levels to unduly influence voters"). The OSCE expressed stronger reservations about Russia's 2003 parliamentary and its 2004 presidential elections, complaining of bias in the state-controlled media and abuses by some local officials, although it still praised the Central Election Commission for its "professional" organization of the elections.

As for voter apathy, turnout in Russian elections since 1991 never dipped below about 54 percent and rose as high as 75 percent in 1991-compared to about 50-51 percent of the voting age population in recent U.S. national elections. In all Russian national elections since 1993, voters had the option to vote "against all" candidates. The number doing so has never exceeded 5 percent.

In a phony democracy, one expects reported election results to match the desires of incumbents. But in Russia, at least before Putin's presidency, the results often shocked political elites. In 1991, an outsider candidate, Boris Yeltsin, beat the favorites of Gorbachev and the Soviet Communist leadership to win the Russian presidency with 57 percent of the vote. In 1993, elites were horrified by the high showing of Vladimir Zhirinovsky and his clownish ultranationalists. In 1995, the Communist Party surprised observers by coming first in the party list vote, with 22 percent, a feat it repeated in 1999, when it won 24 percent. The main party associated with the incumbent regime won only about 15 percent in 1993 and 10 percent in 1995.

Some falsification and improprieties have definitely occurred. In regional elections, Russian officials have used technicalities to disqualify candidates, and incumbents at all levels have misused state resources to campaign for reelection. Limits on campaign spending have been breached. However, such problems do not appear to go beyond the violations common in middle-income democracies like Mexico or Brazil, where stories of coercion, intimidation and vote buying also abound. ${ }^{11}$

${ }^{10}$ For the OSCE reports on Russian elections, see $\langle$ http://www.osce.org/odihr/index.php?page $=$ elections\&div $=$ reports\&country $=\mathrm{ru}\rangle$. To compare with election reports on other countries, see $\langle$ http: $/ /$ www.osce.org/odihr/index.php?page $=$ elections\&div=reports $\rangle$. For the CSCE reports mentioned in the text, see $\langle$ http://www.csce.gov/reports.cfm $\rangle$.

${ }^{11}$ For instance, in Mexico international election observers from the human rights group Global Exchange reported after the 2000 presidential election that in "most of the communities [where its observers were stationed] voting day was marred by often flagrant violations of the electoral code. In the 
Many have attacked Russia's "super-presidentialist" constitution, which was drafted by presidential appointees and endorsed by a 1993 referendum in which the turnout figures have been questioned. While this constitution clearly tilts the balance of power in favor of the executive, it hardly renders Russia's system undemocratic. For example, the Russian constitution allows the president to issue decrees on matters on which the laws are silent. But these decrees can be overruled by the Duma (albeit with a two-thirds majority) or ruled unconstitutional by the Constitutional Court. In this regard, Russia is not very different from the presidential democracies of Argentina and Brazil.

In the last few years, President Putin has stepped up efforts to scare off potential political rivals. The arrest of Mikhail Khodorkovsky was widely believed to be designed to punish the oil tycoon for funding liberal political parties. The October 2003 and August 2004 presidential elections in Chechnya, both of which brought to power the Kremlin's current favorite, had all the credibility of ballots held in the shadow of a tank. The December 2003 parliamentary election clearly saw official pressures on the media, biased coverage, and harassment of rival campaigns, though at rates comparable to those in previous Russian elections and in other middle-income democracies. That these practices swayed the voters more than in previous elections seems unlikely. Some viewed the high reported vote share for the pro-Putin United Russia party as prima facie evidence of falsification. In fact, the vote share for this party, 37 percent, was almost exactly the total won in 1999 by the two blocs-Unity and Fatherland-All Russia-that had later joined together to form United Russia. Although ballot-stuffing in some regions may have shaded the vote by a few percentage points, the official results were mostly close to those found by independent exit polls. Given that real incomes of the population had grown by an average 10 percent a year since Putin took over, it would be surprising if pro-Putin parties were not popular.

From Malaysia to Venezuela to Argentina, political rivals of incumbent politicians in middle-income countries have ended up in jail in recent years, victims of dubious or at least selective prosecutions. In Mexico, such rivals have been assassinated. In disputed territories from Chiapas to eastern Turkey and Mindanao, elections have been held under the alert watch of the military. Russia's record on democratic practices is unenviable and has shifted recently toward the illiberal end of the spectrum, but it is not unusual.

\section{Freedom of the Press}

Russia's press has come in for particularly harsh scrutiny. Freedom House rates the level of "political pressures, controls, and violence" against the media in

days immediately preceding the vote, episodes of vote-buying, coercion, and intimidation were commonplace... The delegation heard numerous testimonies from opposition supporters of harassment and intimidation, particularly in the marginalized and poor communities." See $\langle$ http://www. globalexchange.org/countries/mexico/dem/gx070400.html . In Brazil, according to one observer, "buying votes is common practice. . . and spawns armies of voters ready to sell their votes for a dish of beans" (Whitaker, 2000). Such observations are anecdotal, of course, but so are the ones used to criticize Russia. 
countries around the world. In its 2002 ratings, Russia scored a 30 on a scale that runs from 0 (best) to 40 (worst), putting it below Iran (Sussman and Karlekar, 2002, pp. 43, 32). Iran, as the report itself pointed out, had imprisoned more journalists than any other country. It had banned 40 newspapers since April 2000 and had sentenced journalists to long prison terms, along with floggings of 30-50 lashes and prohibitions from practicing journalism for years.

Critics of Russia's press environment make two points. In the 1990s, some complained that major television stations and newspapers were controlled by oligarchs, who used them to further favored political or business goals. More recently, critics have focused on the state's efforts to harass and intimidate independent journalists and to close down oligarch-owned media, often on financial pretexts. While the criticisms are not altogether consistent, they both have some validity. However, in these regards, Russia again fits the norm for developing-and some developed-states. Djankov, McLiesh, Nenova and Shleifer (2003) surveyed media ownership in 97 countries. They found that 92 percent of the largest television, radio stations and newspapers in these countries were owned by either families or the state. This pattern was common to just about every country studiedfrom Brazil, Mexico, Argentina and South Korea, to Italy, Singapore and Australia. On average, families controlled 57 percent of newspapers and 34 percent of television stations. By this standard, Russia-along with its postcommunist peersstands out among middle-income democracies for the relatively large share of television stations and major newspapers owned by the government.

Press barons throughout the developing world slant the political coverage on their networks to help favored candidates. In many middle-income countries like Argentina and Colombia (Waisbord, 2000) or South Korea (Park, Kim, Sohn, 2000), journalists and their bosses are accused of biasing their reports in return for bribes of cash, "entertainment" and favors in the privatization of media outlets. In Mexico, payoffs to political reporters, often equal to about three months salary, go by the name of chayotes "after a small and tasty squash that fits in the palm of the hand" (Weiner, 2000). Even in rich countries like Italy and the United States, journalists shape their broadcasts to further the political agendas of media tycoons such as Silvio Berlusconi and Rupert Murdoch. ${ }^{12}$

What about state harassment of the press? A single case of repression is already one too many. But state interference with news organizations is-sadly-almost universal among middle-income countries and occurs even in some highly devel-

12 On Rupert Murdoch's Fox television network, see Neil Hickey, "Is Fox News Fair?” Columbia Journalism Review, March/April 1998, which quotes several former employees of the network complaining of "'management sticking their fingers' in the writing and editing of stories and of attempting to cook the facts to make a story more palatable to right-of-center tastes." On Italian television news under Silvio Berlusconi, see, for instance Philip Willan, "Opposition 'kept off Berlusconi-run TV,'” The Guardian, August 8, 2002, which cites a University of Pavia study that found a sharp reduction in the amount of news time devoted to the opposition to Berlusconi after Berlusconi's appointees took over at the RAI network. 
oped ones. The International Press Institute in Vienna collects figures on various kinds of state interference with journalism in the countries of the OSCE and has published these for the 1999-2000 period. Of the 48 countries monitored, 26 had at least one incident in which media were censored or journalists were imprisoned or sentenced to "excessive" fines. In comparing the severity of such repression across countries, one possibility is to compare the total number of incidents in different countries. Within the OSCE, the total ranged from zero (for many countries) to 121 (for Turkey). On this measure, Russia looks relatively bad, coming in second place with 30 incidents during the two years.

However, to compare the absolute number of newspaper closures in a country with hundreds of daily newspapers (like Russia) to the number in a country with just three newspapers (like Macedonia) seems questionable. An alternative approach is to deflate the number of incidents of state interference by the number of media outlets. We could not find cross-national data on the number of television and radio stations, but UNESCO publishes estimates of the number of daily newspapers in countries around the world. Russia, as of the mid-1990s, had 285 (plus about 4,600 nondaily newspapers). Table 2 shows the number of cases of state censorship, imprisonment of journalists and suppression of journalists "by law" per daily newspaper in the OSCE countries. ${ }^{13}$ Of course, these measures are imperfect. If journalists are effectively intimidated, then a repressive state may not need to intervene to silence criticism, and its interventions may go unreported if it does. Dividing by the number of newspapers is a rough-and-ready adjustment-although likely to be less misleading than the raw numbers. By the deflated number, Russia's record of state interference with press freedom is only a little worse than average. Fifteen OSCE countries had poorer records in these years, including Ukraine, Belarus, Turkey, Cyprus and even Austria.

Russia's problems with press freedom, although more widely reported in the West, are not very different from those in various other middle-income countries. In 2000-2001, Putin's government hounded the tycoons Berezovsky and Gusinsky out of the media business. At the same time, a strikingly similar campaign was unfolding in South Korea. In what was widely perceived as a politicized effort by President Kim Dae-jung to punish newspapers critical of his government, the Korean National Tax Service and Fair Trade Commission investigated 23 media companies and assessed them with multimillion-dollar fines. Prosecutors arrested executives from the three conservative newspapers most critical of President Kim and held them in solitary confinement. Kim's aide, Roh Moo-hyun, who later replaced him as president, reportedly said that the newspapers were "no different from organized crime" and told reporters he planned to nationalize them.

Since Putin's rise to power, criticism of the president on Russian national television has been effectively suppressed. This contrasts with major daily newspapers such as Izvestia, Kommersant and Nezavisimaya Gazeta, in which criticism of Putin

\footnotetext{
13 "Suppression by law" covers cases in which journalists were sentenced to prison or excessive fines, including libel suits aimed at impeding the journalist's right to report freely; the introduction of restrictive legislation; and official denial or suspension of credentials.
} 
Table 2

\section{Cases of State Censorship, "Suppression by Law" and Imprisonment of Journalists in OSCE Countries, 1999-2000}

\begin{tabular}{|c|c|c|c|}
\hline \multirow{2}{*}{$\begin{array}{l}\text { Absolute number } \\
\text { Turkey }\end{array}$} & \multicolumn{3}{|c|}{ Per daily newspaper } \\
\hline & 121 & Uzbekistan & 3.33 \\
\hline Russian Federation & 30 & Azerbaijan & 2.33 \\
\hline Azerbaijan & 14 & Turkey & 2.12 \\
\hline Kazakhstan & 10 & Bosnia & 2.00 \\
\hline Uzbekistan & 10 & Kyrgyzstan & 1.67 \\
\hline Belarus & 9 & Belarus & 1.13 \\
\hline Ukraine & 8 & Cyprus & 0.67 \\
\hline Hungary & 7 & Macedonia TFYR & 0.33 \\
\hline Bosnia & 6 & Armenia & 0.27 \\
\hline Cyprus & 6 & Croatia & 0.20 \\
\hline Kyrgyzstan & 5 & Ukraine & 0.18 \\
\hline United Kingdom & 5 & Austria & 0.18 \\
\hline Armenia & 3 & Hungary & 0.18 \\
\hline Austria & 3 & Estonia & 0.13 \\
\hline Greece & 3 & Lithuania & 0.11 \\
\hline Croatia & 2 & Russian Federation & 0.11 \\
\hline Czech Republic & 2 & Czech Republic & 0.10 \\
\hline Estonia & 2 & Slovakia & 0.05 \\
\hline Italy & 2 & United Kingdom & 0.05 \\
\hline Lithuania & 2 & Netherlands & 0.03 \\
\hline Germany & 1 & Italy & 0.03 \\
\hline Macedonia TFYR & 1 & Greece & 0.02 \\
\hline Netherlands & 1 & & \\
\hline Slovakia & 1 & & \\
\hline Turkmenistan & 1 & & \\
\hline United States & 1 & & \\
\hline 23 countries with zero: & & 24 countries with zero: & \\
\hline $\begin{array}{l}\text { Albania, Belgium, Bulgaria, } \\
\text { Canada, Denmark, } \\
\text { Finland, France, Georgia, } \\
\text { Iceland, Ireland, Latvia, } \\
\text { Luxembourg Malta, } \\
\text { Moldova, Norway, Poland, } \\
\text { Portugal, Romania, } \\
\text { Slovenia, Spain, Sweden, } \\
\text { Switzerland, Tajikistan }\end{array}$ & & $\begin{array}{l}\text { Germany, United States, } \\
\text { Albania, Belgium, } \\
\text { Bulgaria, Canada, } \\
\text { Denmark, Finland, } \\
\text { France, Iceland, Ireland, } \\
\text { Latvia, Luxembourg } \\
\text { Malta Moldova, Norway, } \\
\text { Poland, Portugal, } \\
\text { Romania, Slovenia, } \\
\text { Spain, Sweden, } \\
\text { Switzerland, Tajikistan }\end{array}$ & \\
\hline
\end{tabular}

Source: Data from International Press Institute and UNESCO.

remains frequent and bitter. (Skeptics often note that these newspapers have relatively small readerships, but this is like saying the U.S. press is not free because only a fraction of citizens choose to subscribe to the Washington Post or the New York Times.) Despite national television's timid approach to political commentary, to compare such stations to their Soviet era counterparts-as some now do-is to distort reality. In fact, they provide far more information to viewers and fewer 
ideologically motivated lies. The difference is vividly apparent in the coverage of national tragedies. In 2002, the NTV channel provoked the Kremlin's fury for running live footage as Russian troops stormed a Moscow theater that had been seized by Chechen terrorists. This did not stop NTV from broadcasting almost round-the-clock when, in 2004, terrorists captured a school in Beslan, North Ossetia. All three national channels showed harrowing pictures of children emerging, shell-shocked and wounded, from the school and being ferried to hospital in civilian cars because of the shortage of ambulances standing by. It is inconceivable that such scenes would have been televised 20 years ago.

\section{Corruption}

In the late 1990s, the then Chairman of the U.S. House Banking Committee, James Leach (1999a, b), wrote that he had made a study of the world's most corrupt regimes, including the Philippines under Marcos, Zaire under Mobutu and Indonesia under Suharto. Bad as these were, each was outdone by the "pervasiveness of politically tolerated corruption" in postcommunist Russia. Other perceptions of corruption in Russia are equally grim. The anticorruption advocacy group Transparency International (TI) compiles annual ratings of countries' "perceived corruption," based on a range of business surveys. The World Bank has compiled a similar composite rating. Both of these make use, predominantly though not entirely, of surveys of business people or ratings by business consultancies based outside the relevant countries. In both ratings, Russia scores toward the bottom. For instance, in the 2001 version of the World Bank's "graft" index, Russia was 142 out of 160 countries. In TI's 2002 corruption perceptions index, Russia ranked 71 out of 102 countries.

But what about sources less dependent on the perception of outsiders? In summer 1999, the World Bank and the European Bank for Reconstruction and Development (EBRD) conducted a survey of business managers in 22 postcommunist countries. They asked respondents to estimate the share of annual revenues that "firms like yours" typically devoted to unofficial payments to public officials "in order to get things done." Such payments might be made, the questionnaire added, to facilitate connection to public utilities, to obtain licenses or permits, to improve relations with tax collectors or in relation to customs or imports. They also asked respondents to what extent the sale of parliamentary laws, presidential decrees, court decisions and such had directly affected their business, in the hope of measuring the extent to which policymakers were co-opted by business interests (Hellman, Jones, Kaufmann and Schankerman, 2000).

Comparing Russian business managers to their peers in other postcommunist countries, Russia falls in the middle on both the "burden of bribery" and "state capture" dimensions. If one graphs per capita GDP on the horizontal axis and these measures of corruption on the vertical axis, Russia is almost exactly on the ordinary least squares regression line in both cases. Administrative corruption is very high in the really poor countries, such as Uzbekistan, Armenia and Azerbaijan, lower in 
Figure 3

\section{Administrative Corruption in Postcommunist Countries, EBRD Survey of Business Managers, 1999 (BEEPS)}

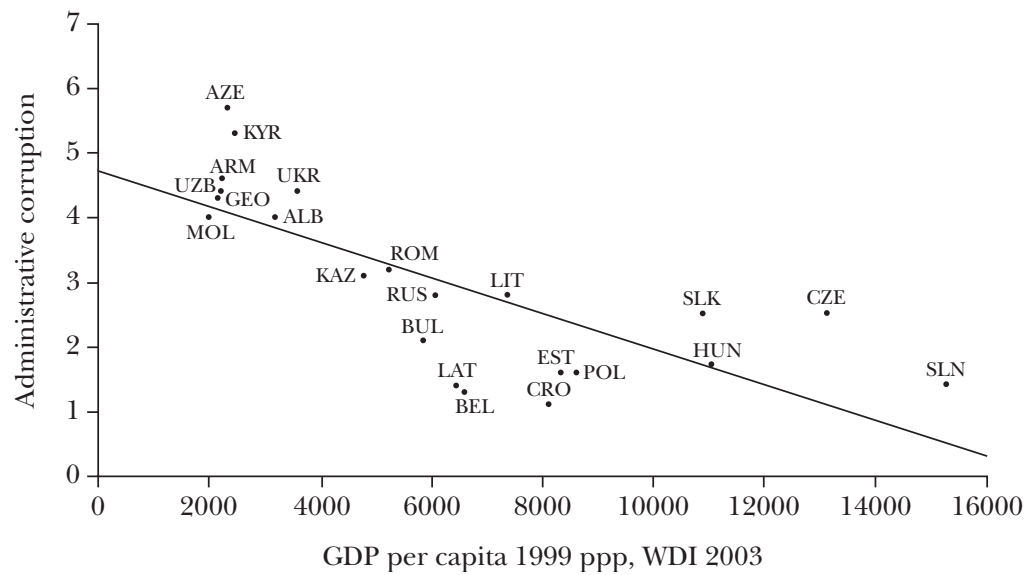

Source: EBRD.

Note: "Administrative corruption" = percentage of revenues paid in bribes by "firms like yours."

Russia, Bulgaria and Lithuania, and lower still in the relatively rich Hungary and Slovenia, as shown in Figure 3. ${ }^{14}$

How does corruption in Russia affect individuals? The United Nations conducts a cross-national survey of crime victims. In 1996-2000, it asked urban respondents in a number of countries the following question: "In some countries, there is a problem of corruption among government or public officials. During-last year-has any government official, for instance a customs officer, a police officer or inspector in your country asked you, or expected you, to pay a bribe for his service?" The proportion of respondents saying they had experienced demands for or expectations of bribes in the last year in Russia (16.6 percent) was lower than that in Argentina, Brazil, Romania or Lithuania, as shown in Table 3. Again, a simple regression shows that the rate for Russia is almost exactly what one would expect given its per capita GDP (Del Frate and van Kesteren, 2003; also United Nations, 2003, Table 21).

Looking at crime in general, the reported victimization rate in Russia is not particularly high. Only 26 percent of Moscow respondents said in 2000 that they had been victimized the previous year by property crimes, robbery, sexual assault, assault, or bribery-compared to 34 percent in Prague, 41 percent in Tallin (Estonia), 44 percent in Rio de Janeiro, and 61 percent in Buenos Aires. Moscow's

\footnotetext{
${ }^{14}$ The World Bank and EBRD repeated the survey in 2002. In almost all countries, the average percent of revenues paid in bribes dropped-it fell in Russia during these three years from 2.8 to 1.4 percent. But the cross-national pattern was almost the same. Again, Russia's level of administrative corruption was slightly lower than would be predicted from its income. And by 2003, it had become less corrupt on the administrative corruption scale than Bulgaria and Belarus.
} 
Table 3

\section{Percentage of Respondents Who Had Been Victimized by Administrative Bribery, 1996-2000, Major Cities}

\begin{tabular}{lllr}
\hline \hline Albania & 59.1 & Slovak Republic & 13.5 \\
Argentina & 30.2 & Paraguay & 13.3 \\
Indonesia & 29.9 & Hungary & 9.8 \\
Bolivia & 24.4 & Croatia & 9.5 \\
India (Mumbai) & 22.9 & Estonia & 9.3 \\
Lithuania & 22.9 & Costa Rica & 9.2 \\
Mongolia & 21.3 & Macedonia, FYR & 7.4 \\
India (New Delhi) & 21.0 & South Africa & 6.9 \\
Azerbaijan & 20.8 & Czech Republic & 5.7 \\
Belarus & 20.6 & Philippines & 4.3 \\
Colombia & 19.5 & Botswana & 2.8 \\
Uganda & 19.5 & Netherlands & 0.9 \\
Kyrgyz Republic & 19.3 & Northern Ireland & 0.8 \\
Romania & 19.2 & Denmark & 0.5 \\
Brazil & 17.1 & Scotland & 0.5 \\
Russian Federation & 16.6 & Finland & 0.4 \\
Georgia & 16.6 & England and Wales & 0.3 \\
Bulgaria & 16.4 & Sweden & 0.2 \\
Ukraine & 16.2 & Spain (Barcelona) & 0 \\
Latvia & 14.3 & & \\
\hline
\end{tabular}

Source: UN International Crime Victims Surveys, UN Human Development Report, 2002, Table 21, and Alvazzi del Frate and J. van Kesteren, "Some Preliminary Tables from the International Crime Victims Surveys," Criminal Victimisation in Urban Europe, UNICRI, Turin, 2003.

rate was almost exactly that reported by urban respondents in Finland (26.6 percent) and lower than that for England and Wales (34.4 percent) (Del Frate and van Kesteren, 2003).

\section{Conclusion}

Russia's economy is no longer the shortage-ridden, militarized, collapsing bureaucracy of 1990. It has metamorphosed into a marketplace of mostly private firms, producing goods and services to please consumers instead of planners. The economy has been growing at an impressive pace. The country's political order, too, has changed beyond recognition. A few business magnates control much of the country's immense raw materials reserves and troubled banking system, and lobby hard behind the scenes for favored policies. Small businesses are burdened by corruption and regulation. Still, the dictatorship of the party has given way to electoral democracy. Russia's once all-powerful Communist Party no longer penetrates all aspects of social life nor sentences dissidents to Arctic labor camps. Instead, it campaigns for seats in parliament. The press, although struggling against heavy-handed political interventions, is still far more professional and independent 
than the stilted propaganda machine of the mid-1980s. In slightly over a decade, Russia has become a typical middle-income, capitalist democracy.

So why the dark-at times almost paranoid-view? Why the hyperbole about kleptocracy, economic cataclysm and KGB takeovers? Why are Russian conditions often portrayed as comparable to those in Zaire or Iran, rather than to the far more similar realities of Argentina or Turkey?

Although many factors may have been involved, we believe that the exaggerated despair over Russia was fueled by a fundamental and widespread misconception. ${ }^{15}$ Many Western observers thought that, as of the early 1990s, Russia was a highly developed, if not wealthy, country. With its brilliant physicists and chess players, its space program and its global military influence, Russia did not look like Argentina or South Korea. Thinking that Russia started off highly developed, these observers saw its convergence to the norm for middle-income countries as a disastrous aberration. The same misconception informed some academic analyses. One recent paper, for example, makes the remarkable observation that although institutions to support the rule of law are imperfect in all countries, "between Russia and most other developed, capitalist societies there was a qualitative difference" (Hoff and Stiglitz, 2002). Indeed, there was a qualitative difference. Russia was never a "developed, capitalist society."

Such misconceptions have important consequences for western policy toward Russia. They predispose decision makers to overreact to the inevitable volatility of Russian economic and political life. The result is extreme mood swings in the West's approach to Russia. When things go "well," markets and political leaders respond with enthusiastic rhetoric, ratcheting expectations up to ever more unrealistic levels. When things go "badly," western Russia-watchers are prone to panic or denunciations and too ready to consider changing course completely. The discourse changes in a matter of days from one of partnership to one of isolation and containment. Such exaggerated swings are not helpful to either Russia or the West.

What does the future hold for Russia? Some see the sudden spurt of growth over the last five years as an indicator of more to come and expect Russia soon to join Hungary and Poland in the community of poor developed countries, leaving behind the middle-income developing ones. They emphasize the country's advanced human capital, its reformed tax system and its mostly open economy. Others see a serious barrier to growth in the bureaucratic regulations and politicized interventions. In politics, optimists anticipate continuing expansion of democratic competition and the emergence of a more vigorous civil society. Pessimists see an accelerating slide toward an authoritarian regime that will be managed by security service professionals under the fig-leaf of formal democratic procedures.

None of these predictions can be ruled out. However, thinking about Russia as

${ }^{15}$ Contributing factors may have included unreflective but sincere sympathy on the part of Western publics for Russians dislocated by the transition; sensationalism in the press; schadenfreude on the part of left-wing intellectuals, for whom turmoil in Russia proved the foolishness of liberal market reforms; and presidential politics in the United States, where Republicans sought to discredit Clinton and Gore, who had consistently supported Yeltsin. 
a normal, middle-income country suggests the implausibility of extreme forecasts. Middle-income countries rarely revert from democracy to full-fledged authoritarianism, although they often renegotiate the boundary between the two. Their democracies are incomplete, unpredictable and subject to temporary reversals. When they grow at all, middle-income countries tend to grow in spurts that are often interrupted by financial crises. Russia has probably destroyed enough of the vestiges of central planning to stay a market economy, albeit one with flawed institutions and much counterproductive state intervention. Its bureaucracy will remain corrupt, although it will become less corrupt as the country grows richer.

That Russia is only a normal middle-income democracy is, of course, a disappointment to those who had hoped for or expected more. But that Russia today has largely broken free of its past, that it is no longer "the evil empire," threatening both its own people and the rest of the world, is an amazing and admirable achievement.

- We thank Anders Aslund, Olivier Blanchard, David Cutler, Lev Freinkman, Miriam Golden, Stephen Hanson, Arnold Harberger, James Hines, Jack Hirshleifer, Simon Johnson, David Laibson, Ed Leamer, Dwight Perkins, Lawrence Summers, Timothy Taylor, Judith Thornton, Michael Waldman and participants at seminars at the University of Washington, U.C. Irvine, U.C. San Diego, and the 2004 AEA meetings for comments. A shorter version of this article appeared in Foreign Affairs, March/April 2004.

\section{References}

Aron, Leon. 2002. "Structure and Context in the Study of Post-Soviet Russia: Several Empirical Generalizations in Search of a Theory." Working paper, American Enterprise Institute.

Aslund, Anders. 2002. Building Capitalism. Cambridge: Cambridge University Press.

Aslund, Anders. 2003. "Moscow Thrives." Memorandum.

Blanchard, Olivier and Michael Kremer. 1997. "Disorganization." Quarterly Journal of Economics. 112:4, pp. 1091-126.

Boone, Peter and Denis Rodionov. 2001. "Rent Seeking in Russia and the CIS." Paper presented at the tenth anniversary conference of the EBRD, London, December.

Claessens, Stijn, Simeon Djankov and Larry Lang. 1999. "The Separation of Ownership and Control in East Asian Corporations." Journal of Financial Economics. 58:1-2, pp. 81-112.
DaVanzo, Julie and Clifford Grammich. 2001. Russia's Mortality Crisis: Drinking, Disease, and Deteriorating Health Care. Santa Monica: Rand Corporation.

Del Frate, Alvazzi and J. van Kesteren. 2003. "Some Preliminary Tables From the International Crime Victim Surveys," in Criminal Victimisation in Urban Europe. Turin: United Nations Interregional Crime and Justice Research Institute, forthcoming.

Djankov, Simeon, Caralee McLiesh, Tatiana Nenova and Andrei Shleifer. 2003. "Who Owns the Media?" Journal of Law and Economics. 46:2, pp. 341-82.

European Bank for Reconstruction and Development. 1999. Transition Report 1999: Ten Years of Transition. London: EBRD.

Faccio, Mara. 2003. "Politically-Connected Firms.” Mimeo, Vanderbilt University. 
Gastil, Raymond. 1992. Freedom in the World, 1991-1992. Washington: Freedom House.

Gibson, John, Steven Stillman and Trinh Le. 2004. "CPI Bias and Real Living Standards in Russia During the Transition." Unpublished paper, Wellington, New Zealand.

Goldman, Marshall. 2003. The Piratization of Russia: Russian Reform Goes Awry. New York: Routledge.

Goskomstat Rossii. 1994. Rossiiskiy Statisticheskiy Yezhegodnik 1994. Moscow, Russia: Goskomstat Rossii.

Goskomstat Rossii. 2001. Rossiiskiy Statisticheskiy Yezhegodnik 2001. Moscow, Russia: Goskomstat Rossii.

Guriev, Sergei and Andrei Rachinsky. 2004. Ownership Concentration in Russian Industry. Washington, D.C.: World Bank.

Hellman, Joel, Geraint Jones, Daniel Kaufmann and Mark Schankerman. 2000. Measuring Governance Corruption and State Capture: How Firms and Bureaucrats Shape the Business Environment in Transition Economies. London and Washington: EBRD and World Bank.

Hickey, Neil. 1998. "Is Fox News Fair?" Columbia Journalism Review. March/April; Available at 〈http://archives.cjr.org/year/98/2/fox.asp〉.

Hoff, Karla and Joseph Stiglitz. 2002. "After the Big Bang? Obstacles to the Emergence of the Rule of Law in Post-Communist Societies." NBER Working Paper No. 9282.

International Monetary Fund. 2002. International Financial Statistics. Washington, D.C.: IMF.

Johnson, Simon, Daniel Kaufmann and Andrei Shleifer. 1997 "The Unofficial Economy in Transition." Brookings Papers on Economic Activity. 2, pp. 159-221.

Johnson, Simon, Rafael La Porta, Florencio Lopez-de-Silanes and Andrei Shleifer. 2000. "Tunneling." American Economic Review. 90:2, pp. 22-27.

La Porta, Rafael, Florencio Lopez-de-Silanes and Andrei Shleifer. 1999. "Corporate Ownership around the World." Journal of Finance. 54:2, pp. 471-517.

Leach, James. 1999a. "The New Russian Menace." New York Times. September 10, p. A25.

Leach, James. 1999b. "Opening Statement of Representative James A. Leach," in "Hearing on Russian Money Laundering." U.S. House of Representatives, Committee on Banking and Financial Services, September 21; Available at 〈http:/ / financialservices.house.gov/banking/92199lea. htm).

Milanovic, Branko. 1998. Explaining the Growth in Inequality During the Transition. Washington: World Bank.

Murphy, Kevin, Andrei Shleifer and Robert
Vishny. 1992. "The Transition to a Market Economy: Pitfalls of Partial Reform." Quarterly Journal of Economics. 107:3, pp. 889-906.

Myers, Steven Lee. 2003. "In Russia, Apathy Dims Democracy..., , New York Times. November 9, Section 4, pp. 1, 5 .

New York Times. 2000. October 29, p. 12.

Park, Myung-Jin, Chang-Nam Kim and ByungWoo Sohn. 2000. "Modernization, Globalization, and the Powerful State: The Korean Media," in De-Westernizing Media Studies. James Curran and Myung-Jin Park, eds. New York: Routledge, chapter 8 .

Safire, William. 2003a. "The Russian Reversion." New York Times. December 10.

Safire, William. 2003b. "Siloviki versus Oligarchy." New York Times. November 5.

Sanders, Bernard. 1998. "Sanders: American Taxpayers Shouldn't Fund IMF's Russian Failure." September 10; Available at 〈http://www .house.gov/bernie/press/1998/09-10-98.html>.

Schmitt, Eric. 1999. "Republicans Step Up Attack on Clinton's Russia Policy." New York Times. September 15, p. A12.

Shkolnikov, Vladimir, Giovanni Cornia, David Leon and France Meslé. 1998. "Causes of the Russian Mortality Crisis: Evidence and Interpretations." World Development Report. 26:11, pp. 1995-2011.

Stiglitz, Joseph. 2002. Globalization and Its Discontents. New York: W. W. Norton.

Sussman, Leonard and Karin Karlekar, eds. 2002. The Annual Survey of Press Freedom, 2002. New York: Freedom House.

U.S. Department of State. 2003. "President Bush Meets with Russian President Putin at Camp David." September 27; Available at $\langle$ http://www .state.gov/p/eur/rls/rm/2003/24608.htm .

United Nations. 2003. Human Development Report 2002. New York: United Nations.

Waisbord, Silvio. 2000. "Media in South America: Between the Rock of State and the Hard Place of the Market," in De-Westernizing Media Studies. James Curran and Myung-Jin Park, eds. New York: Routledge, chapter 4.

Weiner, Tim. 2000. "Mexico Ending Coziness For Press and Powerful." New York Times. October 29, p. 12.

Whitaker, Chico. 2000. "Brazil's Free Elections." Le Monde Diplomatique. September; Available at 〈http://mondediplo.com/2000/09/ 15brazil $\rangle$.

World Bank. 2000. World Development Report. Washington: The World Bank.

Willan, Philip. 2002. "Opposition 'Kept Off Berlusconi-Run TV."” The Guardian, August 8; Available at 〈http://www.guardian.co.uk/italy/ story/0,12576,824149,00.html . 